Tadeusz Pabjan

The Pontifical University of John Paul II in Krakow, Poland

\title{
Some remarks on the conflict between faith and science
}

\begin{abstract}
This paper deals with the conflict between faith and science. Since the issue is extensive, only selected aspects of this question are discussed. At first, the origin of the problem is outlined - it is argued, that the fundamental difference between the language and the method of science on one hand and of theology understood as a rational reflection on the truths of faith on the other is responsible for the conflict. Afterwards, two aspects of the conflict are presented - the first one concerns inconsistencies which appear on the plane of content - when some scientific statements or theorems seem to deny some theological claims; the second one involves differences in mentality and in worldview which appear on the plane of attitude. It is argued, that the content discrepancies can be eliminated with the help of two methods: of separation and of catharsis. But the differences in mentality which appear on the plane of attitude cannot be so easily eliminated. So finally the characteristics of these two different attitudes - of faith and of science - is discussed. It is argued, that a fundamental dissimilarity between the character of scientific knowledge (especially its empiricism) and of religious faith is a basic source of mutual estrangement and alienation.
\end{abstract}

\section{Keywords}

Faith, science, conflict between faith and science, separation, catharsis, complementarity.

A great deal has been written and said so far about the so called conflict between faith and science, and it is not easy to say something new and revealing - 
especially in such a short paper as this one. But even short papers can sometimes contain valuable reflections - their advantage over exhaustive books may consists in presenting an accurate summarizing and conclusions, which somewhere else are narrated wordily and vaguely. Undoubtedly, the problem of mutual relations between religion and science is complicated and intricate, and instead of talking about all its aspects it is good to concentrate on some concrete questions, which can easily be solved.

First of all, certain restrictions are needed here. When talking about faith, we will ignore in this article "secular" faith, which is nothing more but an ordinary conviction about something (e.g. that the weather tomorrow will be good) or an acceptance of some information without its verification (e.g. that the Earth is not flat). Into account will be taken only religious faith, which is a conviction or a belief accepted on the grounds of the authority of God who reveals the truth about Himself (e.g. that God exists). Obviously, one can talk about a conflict between faith and science with reference to every single religion, but in this paper we will limit ourselves only to Christianity - a religion that shaped the history of Europe in which science was born.

There are many reasons for which it is not easy to discuss the problem of conflict between faith and science - it is a multifaceted and interdisciplinary question, which is perceived differently by scientists, philosophers, theologians, and by outsiders who make their opinion about this conflict on the basis of what they can find in the mass media. Furthermore, the interpretation of this issue depends strongly on the accepted worldview. In a sense, it is a controversial problem, too - even Christian philosophers and theologians themselves do not agree about the relation between faith and science, and what is the best model of interaction between these two different domains.

\section{Origin of the conflict}

When searching for the sources of the conflict between faith and science, one has to look back into the remote past, where the very beginning of human science as well as of theology can be traced. The first stirrings of science occurred when the process of demythologisation of nature began in ancient times and when some Greek philosophers tried for the very first time in the whole history to explain the world in a natural way - i.e., without appealing to gods which incessantly 
influence on the nature ${ }^{1}$. This method of explanation evolved and with time it turned into what is presently called the scientific method. Precisely defined concepts, the use of mathematics, and the fundamental role of experiment are the main elements of this method.

It seems that the first conflict between faith and science appeared when theology - understood as some kind of rational reflection on the truths of faith - came to existence. The fundamental difference between what theology is and what science is, justifies this conflict. There are various definitions of the theology, each one emphasizing that theology comes from the connection of human thought with something which is not human, and which claims to be a revealed truth ${ }^{2}$. And there is no doubt that science had from the very beginning the most important influence on human thought. Even if for a long time these "pre-scientific studies" were part of the philosophical discourse, these prepared the ground for the eventual development of science as we understand it today. The germs of conflict between faith and science reside just in this circumstance. When the human thought, influenced by science, meets the Thought which is not human, and which, in addition, is expressed in terms of scientific language, misunderstanding has to appear ${ }^{3}$.

One cannot express or communicate the thought - human or not - to other people without enclosing it in words and sentences. No wonder that the first episodes of the conflict were marked with the language problem. Christianity emerged within the limits of the Greek-Roman culture, although its roots were in Judaism. This is why the first theologians - in fact, not only the early Church Fathers and apologists, but also the authors of the books of the New Testament belong to this group - had to measure themselves against the task of expressing the message of the Gospel with the help of language familiar to that culture. There is no doubt that the nature of the message depends in a fundamental way on the language with which it is communicated. Being aware of this dependence, Michael Heller aptly notices that "the essence of the conflict [between faith and

${ }^{1}$ Cf. O. Pedersen, Konflikt czy symbioza? Z dziejów relacji między nauką i teologia, Tarnów 1997, Biblos, p. 27-57.

${ }^{2}$ Cf. M. Heller, Wszechświat i Słowo, Kraków 1994, Wydawnictwo Znak, p. 14-15. The author notices that it is important not to confuse theology with religion: it is theology that comes from the contact of human thought with the revelation, not religion.

${ }^{3}$ Cf. M. Heller, Nowa fizyka i nowa teologia, Tarnów 1992, Biblos. 
science] consists in some kind of tension between the most profound contents of the Christian doctrine and the conceptual and linguistic apparatus, with which this doctrine had to be expressed. Public polemics between representatives of the pagan philosophy and apologists of the young Christianity, or disputes among ecclesiastical writers themselves on the relation to "the Greek wisdom“ were only a consequence and an external indication of that significant tension: between the transcendent contents and the existing means of expression"4.

It should be stressed that this fundamental cause of conflict between faith and science - a principal discrepancy between the transcendent contents and the existing human means of expression - remains present regardless of historical epoch $^{5}$. A gradual development of philosophy and of science caused an evolution of the human thought, and led to important changes in the worldview. No wonder that the language itself continuously evolved too. But the problem with that discrepancy remained. Today - in the beginning of XXI century - this problem is just the same as it was when Christianity emerged, two thousand years ago. The notions and phrases of a present-day language are equally incapable of grasping and expressing the contents of Christian doctrine. This form of conflict between human faith and human thought is unavoidable. And because the human thought is strongly influenced by science, it is at the same time a conflict between faith and science ${ }^{6}$.

Another aspect of the same problem appears when one realizes that human thought easily comes into conflict with faith, because thought means reason, and this is an essential difference - or even more: it is a principal point of opposition between faith and reason. The whole history of theology is marked with this opposition. The contention about the relation between faith and reason, and about the role of human intellect in the process of explaining and interpreting the Revelation, lasted continuously from the times of the Church Fathers, and intensified in the Middle Ages. This contention contributed to a gradual separation of competences between philosophy (only human reason) and theology (human reason supported by the Revelation), and to a gradual limitation of reason's competences in the domain of faith ${ }^{7}$. Even today, there

${ }^{4}$ M. Heller, Wszechświat i Słowo, p. 17.

${ }^{5}$ Cf. M. Heller, Teologia i wszechświat, Tarnów 2009, Biblos, p. 21-84.

${ }^{6}$ Cf. A. McGrath, Nauka i religia, Kraków 2009, Wydawnictwo WAM; D. Dennett, A. Plantinga, Nauka i religia. Czy można je pogodzić?, Kraków 2014, Copernicus Center Press.

${ }^{7}$ Cf. M. Heller, Wszechświat i Słowo, p. 18-19. 
is no full agreement between theologians about the range of this limitation. Some of them still think - despite the clear and unequivocal documents as Fides et Ratio of St. John Paul II - that reason is not a supporter, but a rival of faith. Such attitudes - even if infrequent - favor a climate of conflict between faith and science, because science always was a domain of reason.

\section{Two aspects of the conflict}

Intuitively, it is easy to grasp what the conflict between faith (or theology) and science consists in: there are two distinct domains, which can be only described by completely different languages and explored by means of quite disparate methods ${ }^{8}$. But what exactly such a conflict means? One can distinguish two aspects or two kinds of the conflict. The first one concerns inconsistencies which appear on the plane of content - when some scientific statements or theorems seem to deny some theological claims; the second one involves differences in mentality and in world-view which appear not on the plane of content, but on the plane of attitude. The history of this problem shows, that these two aspects of the conflict between faith and science did not emerge at the same time - they succeeded chronologically. For this reason, one can regard these two aspects as two consecutive phases of the conflict: at first, the conflict appeared, and for a long time evolved and intensified, on the plane of content, but later it turned out that content inconsistencies are less important than differences in world-view, and the conflict moved to the plane of attitude. There are reasons to believe that today the content problems are basically solved, and this is why all the current episodes of the conflict are taking place just on the plane of attitude?

${ }^{8}$ Cf. M. Tałasiewicz, Nauka i teologia: konflikt wyobrażeń, „Zagadnienia Filozoficzne w Nauce” 44 (2009), p. 116-146.

9 "When looking at development of relations between faith and knowledge in the modern times, one can notice a clear displacement of the accents. At first some theorems of science seemed to deny some religious truths. This tied, and then sharpened the problem. With time, the dissenting opinions of science and faith are becoming less important, while bigger and bigger role plays the difference in mentality. It leads to a distinction in the whole dispute the two planes: the plane of content and the plane of attitude. The contention originated on the plane of content, but it moves more and more on the plane of attitude". M. Heller, Wszechświat i Stowo, p. 27. 
The content discrepancies were eliminated with the help of two methods: the first one can be called a method of separation, the second one - a method of catharsis ${ }^{10}$. As far as the first method is concerned, there is no need to explain what the separation means. The postulate of separation of faith and science or rather of religious and scientific type of cognition - is motivated by several arguments. The most important ones point to differences in methods, languages, and generally, in epistemological character. This is why these two domains faith and science - have two dissimilar and separate extents of competence. Sometimes it is simply said that they are two separate (or parallel) planes of knowledge, which have no common points.

There is no simple interpretation of how the "parallelism" of these two planes should be understood. Some authors illustrate this disagreement. For example - Stephen J. Gould maintains, that there is no ground for describing any conflict between faith and science, because these two domains remain on two separate, non-intersecting cognitive planes ${ }^{11}$. This outlook was popularized as NOMA, which is an acronym built from the expression "Non-Overlapping Magisteria". Since science and religion relate to completely different aspects of human existence, they cannot get into conflict, and this is why the conflict between them is merely apparent: "it exists only in people's minds and social practices, not in the logic or proper utility of these entirely different, and equally vital, subjects"12. There are no common points between science and religion, because they put different questions, give diverse answers, have quite contrary explanations, use dissimilar methodological criteria, and justify their theses in a different way - this is why the relation between these domains is not the relation of conflict, but of mutual, highly esteemed separation ${ }^{13}$.

A similar, but slightly changed, approach is represented by Francis S. Collins, for whom science and religion are in fact neither in conflict nor in separation,

${ }^{10}$ Cf. J. Ladrière, La science, le monde et la foi, Tournai 1972, Casterman.

${ }^{11}$ Cf. S. J. Gould, Skały wieków. Nauka i religia w pełni życia, Poznań 2002, Wydawnictwo Zysk i S-ka.

12 S. J. Gould, Skały wieków, p. 9.

13 "Magisterium of science covers the empirical realm: what is the universe made of (fact) and why does it work this way (theory). The magisterium of religion extends over questions of ultimate meaning and moral value. These two magisteria do not overlap, nor do they encompass all inquiry (consider, for example, the magisterium of art and the meaning of beauty)". S. J. Gould, Skaty wieków, p. 11. 
but in a relation of mutual complementing ${ }^{14}$. Their magisteria are partially overlapping - this is why such idea can be marked with acronym POMA (Partially Overlapping Magisteria) ${ }^{15}$ - and for this reason both science and religion are dealing with the same problems and answer the same questions. Because of methodological differences between these two domains the same problems are seen from different points of view, and the same questions receive complementing answers. Instead of conflict and isolation there is a common search for harmony and integration in this attitude - the two magisteria are not completely separated and are able to be a reciprocal inspiration for each other.

Another approach is represented by Józef Życiński, whose idea - by analogy with that of Gould and Collins - can be designated by acronym NOCMA (Non-Conflicting Magisteria $)^{16}$. This model of interaction between religion and science emphasizes the absence of conflict or discrepancy, and gives weight to complementarity of these two domains. According to Życiński, to achieve an adequate and complete depiction of reality, one has to resort to an interdisciplinary analysis in which both scientific as well as theological components are taken into account. Such complementarity means, that only taking together these two descriptions one can obtain a comprehensive knowledge about complex and multifaceted universe. In this approach an empirical level of reality explored by science is deepened by taking into consideration a spiritual level described by theology - in such a way, that autonomy of both levels is preserved, and physical reductionism is excluded ${ }^{17}$.

When talking about the relations between cognitive planes of faith and science, is should be noted that - regardless of them overlapping or not - there's no doubt that these two kinds of knowledge (religious and empirical) differ from

${ }^{14}$ Cf. F. S. Collins, The Language of God. A Scientist Presents Evidence for Belief, London 2007, Pocket Books.

15 Cf. A. McGrath, J. C. McGrath, Bóg nie jest urojeniem. Złudzenie Dawkinsa, Kraków 2012, Wydawnictwo WAM. Collins himself characterizes his own idea with the help of term "BioLogos".

${ }^{16}$ Cf. W. Kotowicz, Józefa Życińskiego meta-przedmiotowe ujęcie relacji pomiędzy nauka a religią, „Roczniki Filozoficzne” 60 (2012) 4, p. 249-260; P. Gutowski, Józefa Życińskiego koncepcja relacji pomiędzy religia a nauką, „Przegląd Filozoficzny. Nowa Seria” 1 (2013) 85, p. 15-30.

${ }^{17}$ Cf. J. Życiński, Bóg i ewolucja, Lublin 2002, Wydawnictwo KUL; J. Życiński, Wszechświat emergentny. Bóg w ewolucji przyrody, Lublin 2009, Wydawnictwo KUL; J. Życiński, Transcendencja i naturalizm, Kraków 2014, Copernicus Center Press. 
each other. But approving their dissimilarity one is not forced to diminish any of them. This is why the Życinski's conception, in which both levels of cognition are taken into account, seems the most promising model of interaction between faith and science.

The second of aforementioned methods of eliminating content discrepancies between faith and science is a method of catharsis, which consists in purification of theology - a science undertaking methodological reflection on the contents of religious faith - from all pseudo-scientific and pseudo-dogmatic elements ${ }^{18}$. Today it is obvious that theology is not independent of the development of science, because it cannot explain or interpret the contents of faith without recourse to the world-view which is created out of scientific concepts and discoveries. The entanglement of this system - theology and world-view - is so real that elements of the world-view are sometimes interpreted as the revealed truths. The best example is here the immobility of the Earth in the medieval worldview. Because of the development of science, the world-view changes, and consequently such pseudo-dogmas are eliminated from the scope of theological assertions, and they are no longer treated as ones of the revealed truths. In this context it is sometimes said about the process of "demythologisation" of theology which is caused by the development of science. Even if such a process is painful for theology, its advantages are obvious ${ }^{19}$.

Separation and catharsis are two methods of eliminating conten discrepancies between faith and science. But the differences in mentality which appear on the plane of attitude still remain. What is the nature of these differences? To find an answer to this question one has to remember that it is not just a psychological problem consisting in mutual strangeness or hostility caused by dissimilar mentalities. As a matter of fact, it is an epistemological or even an ontological problem, because different attitudes or mentalities are connected to different cognitive layers of reality, and indirectly - to different ontological interpretations of reality.

${ }^{18}$ Cf. M. Heller, Wszechświat i Słowo, p. 23-26.

19 "It is significant purifying role of science in relation to theology. In connection with this it is sometimes said about demythologisation of theology by the development of secular sciences. Such procedure can be connected with some cuts which are painful for theologians, but firstly - for theology it is a matter of honesty, and secondly - only then theology would have chance to find its way to the man of the future". M. Heller, Wszechświat i Stowo, p. 24. 


\section{The different attitudes}

There are many distinct differences between religious and scientific attitudes which are responsible for the feeling of strangeness and unfamiliarity, but the most important is a fundamental dissimilarity between the character of scientific knowledge and of religious faith. Not accidentally, the conflict between faith and science - although its origin can be traced in antiquity - developed quickly not until empirical sciences appeared in modern times ${ }^{20}$. In fact, empiricism of science turned out to be a basic source of aforesaid strangeness.

There's no doubt that modern sciences were born thanks to the "discovery" of the empirical method ${ }^{21}$. The essence of this method consists in observing, measuring and weighting objects or events belonging to physical universe. The result of such activity is always objective and unambiguous, because empirical knowledge is intersubjectively verifiable: what was observed or measured by one scientist, can always be confirmed by observations and measurements performed by anyone who knows what to observe and how to use the measuring device. There is a permanent dispute in philosophy of science about the meaning of verifiability, but most of the debaters agree that empirical knowledge - acquired with the help of the empirical method, is a certain knowledge. It is often said that science is based on facts only: fact is nothing but the result of an observation or of an experiment ${ }^{22}$. This certainty and objectivity of scientific knowledge constitutes the main difference with the uncertainty and subjectivity of religious faith.

But that is not the only difference. The empirical method is often supported, especially in the domain of physics or cosmology, by mathematics. This makes it even more effectual, and confirms the certainty of scientific knowledge. It is not obvious, why mathematics can be so easily used to describe and to explain behaviour of physical objects - the mathematicity of the universe is still a mystery which has been discussed since long time by philosophers

${ }^{20}$ Cf. G. Minois, Kościół i nauka, Warszawa 1996, Wydawnictwo Bellona; T. Clements, Nauka kontra religia, Warszwa 2002, Wydawnictwo Da Capo.

${ }^{21}$ Cf. A. K. Wróblewski, Historia fizyki, Warszawa 2009, PWN; R. Palacz, Od wiedzy do nauki. U źródeł nowożytnej filozofii przyrody, Warszawa 1979, Wydawnictwo PAN.

${ }^{22}$ Cf. Z. Hajduk, Metodologia nauk przyrodniczych, Lublin 2002, Wydawnictwo KUL; J. J. Davies, On the Scientific Method, London 1968, Longmann; C. W. K. Mundle, Perception. Facts and Theories, Oxford 1971, Oxford University Press. 
of science ${ }^{23}$ - but there's no doubt that such a connection of mathematics and empiricism gives a very effective tool for exploring and modifying the world. The development of technology, which started growing when empirical sciences appeared, is the strongest proof of this effectiveness of mathematico-empirical method. It is another difference to religious faith. Together with aforementioned certainty of scientific knowledge it provides a meaningful explanation of strangeness felt between scientific and religious attitudes.

The contrast between science and faith is easily seen in this light: empiricism, certainty, objectivity and effectiveness of scientific knowledge on the one hand, and thesubjective, abstract, inverifiabile and private characters of religious faith on the other. It is not easy to find any other two domains distinguished by greater discrepancy. There is no doubt, this discrepancy proves that the strangeness of these two attitudes - science and faith - is fundamental, and cannot be eliminated by any scientific or theological endeavour. Heller underlines, that such state of affairs should not be treated as a problem for theology. Furthermore, if the faith is to be authentic, that strangeness has to be continuously sharpened, because faith cannot become a kind of scientific knowledge with its mathematical and empirical obviousness - faith must remain faith, because its very substance is constituted not by certainty, but by the trust in Someone ${ }^{24}$. If one bears in mind that science is exclusively the work of man, whereas religious faith is always an acceptance of something which is not created by man (but is a kind of a divine, revealed information), it is easy to understand where the strangeness of these two attitudes comes from: "the essence of strangeness between "attitude of science" and "attitude of faith" consists in that the first comes "from Earth", and the second - „from Heaven“. Here is the source of the methodological distinctions as well as of all psychological resistances"25.

At this point, it is worth adding that the difference between the two discussed attitudes has very often a close connection with a difference between two dissimilar world-views accepted by a religious man, who believes in God and

${ }^{23}$ Cf. Matematyczność przyrody, M. Heller, J. Życiński, A. Michalik (ed.), Kraków 1992, OBI; E. P. Wigner, Niepojęta skuteczność matematyki w naukach przyrodniczych, „Zagadnienia Filozoficzne w Nauce" 13 (1991), p. 5-18; G. V. Coyne, M. Heller, Pojmowalny Wszechświat, Warszawa 2007, Prószyński i S-ka; M. Tegmark, Nasz matematyczny wszechświat. W poszukiwaniu prawdziwej natury rzeczywistości, Warszawa 2015, Prószyński i S-ka.

${ }^{24}$ Cf. M. Heller, Wszechświat i Słowo, p. 37.

${ }^{25}$ M. Heller, Wszechświat i Słowo, p. 36. 
in the whole spiritual (i.e. immaterial) reality, and by an atheist, who is deeply convinced that only matter exists. Instead of using terms "believer" or "atheist", one can say that these two kinds of people are guided by different philosophies, or more precisely, different ontological interpretations of reality: in the language of philosophy the first case is called a dualism; the second - a materialistic monism, that is, a materialism. Of course, it is not a rule that a scientist must be a materialist, and it is not true that science equals materialism. Science must not be confused with philosophy, and materialism is just a philosophical interpretation. A scientist can be a materialist as well as a dualist; he can believe that only matter exists as well as that there exists immaterial reality besides matter.

But the history of science as well as of philosophy shows that it is not difficult to confuse these two domains, and to treat empirical sciences as the source of information about the ontology of the world. In fact, the modern materialism has its origin just in that reasoning: science deals only with material objects; empirical method - which is very effective - says nothing about immaterial entities, so matter is the only thing that exists ${ }^{26}$. Such a reasoning is an example of a "forbidden" transition between methodology or epistemology (the empirical method of science is based on a rule: let us narrow down the set of explored objects to matter which can be observed and measured) and ontology (which says: only matter exists). It is interesting and symptomatic that although this kind of a "forbidden" transition is a gross methodological error, it is continually repeated by contemporary partisans of the so called scientific materialism (e.g. Richard Dawkins, Stephen Hawking), who claim that it is just science that proves God does not exist.

\section{Concluding remarks}

Undoubtedly, there exists the principal and irremovable difference between religious and scientific cognition, but the acceptance of such difference does not mean that one should deny the existence of one of these two domains. The method of empirical sciences deals with material objects only, but this restriction

${ }^{26}$ Cf. T. Pabjan, O tym co istnieje i co nie istnieje, in: In Nomine Domini. Ksiegga pamiątkowa ku czci Księdza Biskupa Jana Styrny w 50. rocznicę posługi kapłańskiej, S. Sojka, S. Ewertowski (ed.), Wydział Teologii UWM w Olsztynie, Olsztyn - Elbląg 2015, p. 491-501. 
results exclusively from the previously accepted methodology, and cannot be interpreted as the ontological principle. This is why scientific theories say nothing about the existence of anything, they neither prove nor disprove the existence of God. It is because the problem of existence is not physical but a metaphysical question. If science should decide about what exists and what does not exist, it would not be science anymore, it would turn in metaphysics. The effectiveness of an empirical method is the cause of totalitarian tendencies of contemporary science, which manifests themselves in the inclination to reduce everything to the physical level. But such a reductionism, especially in its ontological version, is not justified. The methodological principles must not be confused with the ontological ones.

When talking about the relations between faith and science one should not forget that an autonomy must be granted to these domains, and neither of them can dominate or subordinate the other. History shows, that any interference of religious institutions into the field of science (e.g. the case of Galileo ${ }^{27}$ ) always have regrettable consequences, they are harmful not only for those institutions, but also for religion. Aforesaid interpretations of militants of the so called scientific materialism, according to which science proves God does not exist, are good example of an analogous wrongdoing - it is a forbidden interference of scientists into the field of faith. But the autonomy between faith and science need not necessarily mean a complete separation - even if the cognitive planes of religion and of science are different, there are still possible some interactions between these two domains.

There is no full agreement on how these interactions should look like, several views of different authors were beforehand shortly presented, but it seems that the cognitive planes of faith and science are in fact not parallel; they intersect in such a way that their magisteria are partially overlapping, and although these two kinds of knowledge (religious and empirical) differ from each other, they can be understood as complementary and equally necessary descriptions of reality. Taking into account all previously discussed differences between faith and science, it seems that it is possible to find a model of interaction between these two domains in which a conflict would be turned into complementarity and into a common search for a coherent synthesis of two important aspects of reality. One should hope that such a model will be realised in the future.

${ }^{27}$ Cf. Sprawa Galileusza, J. Życiński (ed.), Kraków 1991, Wydawnictwo ZNAK; E. Namer, Sprawa Galileusza, Warszawa 1985, Czytelnik. 


\section{Bibliography}

Clements T., Nauka kontra religia, Warszwa 2002, Wydawnictwo Da Capo.

Collins F. S., The Language of God. A Scientist Presents Evidence for Belief, London 2007, Pocket Books.

Coyne G. V., Heller M., Pojmowalny Wszechświat, Warszawa 2007, Prószyński i S-ka.

Davies J. J., On the Scientific Method, London 1968, Longmann.

Dennett D., Plantinga A., Nauka i religia. Czy można je pogodzić?, Kraków 2014, Copernicus Center Press.

Gould S. J., Skały wieków. Nauka i religia w pełni życia, Poznań 2002, Wydawnictwo Zysk i S-ka.

Gutowski P., Józefa Życińskiego koncepcja relacji pomiędzy religia a nauką, „Przegląd Filozoficzny. Nowa Seria” 1 (2013) 85, p. 15-30.

Hajduk Z., Metodologia nauk przyrodniczych, Lublin 2002, Wydawnictwo KUL.

Heller M., Nowa fizyka i nowa teologia, Tarnów 1992, Biblos.

Heller M., Teologia i wszechświat, Tarnów 2009, Biblos.

Heller M., Wszechświat i Słowo, Kraków 1994, Wydawnictwo Znak.

Kotowicz W., Józefa Życińskiego meta-przedmiotowe ujęcie relacji pomiędzy naukg a religia, „Roczniki Filozoficzne” 60 (2012) 4, p. 249-260.

Ladrière J., La science, le monde et la foi, Tournai 1972, Casterman.

Matematyczność przyrody, M. Heller, J. Życiński, A. Michalik (ed.), Kraków 1992, OBI.

McGrath A., McGrath J. C., Bóg nie jest urojeniem. Złudzenie Dawkinsa, Kraków 2012, Wydawnictwo WAM.

McGrath A., Nauka i religia, Kraków 2009, Wydawnictwo WAM.

Minois G., Kościół i nauka, Warszawa 1996, Wydawnictwo Bellona.

Mundle C. W. K., Perception. Facts and Theories, Oxford 1971, Oxford University Press.

Namer E., Sprawa Galileusza, Warszawa 1985, Czytelnik.

Pabjan T., O tym co istnieje i co nie istnieje, in: In Nomine Domini. Ksiega pamiattkowa ku czci Księdza Biskupa Jana Styrny w 50. rocznicę posługi kapłańskiej, S. Sojka, S. Ewertowski (ed.), Wydział Teologii UWM w Olsztynie, Olsztyn - Elbląg 2015, p. 491-501.

Palacz R., Od wiedzy do nauki. U źródeł nowożytnej filozofii przyrody, Warszawa 1979, Wydawnictwo PAN.

Pedersen O., Konflikt czy symbioza? Z dziejów relacji między nauka i teologia, Tarnów 1997, Biblos.

Sprawa Galileusza, J. Życiński (ed.), Kraków 1991, Wydawnictwo ZNAK.

Tałasiewicz M., Nauka i teologia: konflikt wyobrażeń, „Zagadnienia Filozoficzne w Nauce” 44 (2009), p. 116-146. 
Tegmark M., Nasz matematyczny wszechświat. W poszukiwaniu prawdziwej natury rzeczywistości, Warszawa 2015, Prószyński i S-ka.

Wigner E. P., Niepojęta skuteczność matematyki w naukach przyrodniczych, „Zagadnienia Filozoficzne w Nauce” 13 (1991), p. 5-18.

Wróblewski A. K., Historia fizyki, Warszawa 2009, PWN.

Życiński J., Bóg i ewolucja, Lublin 2002, Wydawnictwo KUL.

Życiński J., Transcendencja i naturalizm, Kraków 2014, Copernicus Center Press.

Życiński J., Wszechświat emergentny. Bóg w ewolucji przyrody, Lublin 2009, Wydawnictwo KUL. 